\title{
KAIIAN KECANTIKAN KAUM PEREMPUAN DALAM IKLAN
}

\author{
Ira Wirasari \\ Institut Teknologi Bandung
}

\begin{abstract}
Abstrak: Kecantikan kaum perempuan selalu menjadi pembicaraan dan trend tersendiri dalam masyarakat. Kecantikan kaum perempuan yang sangat beragam tidak terbatas pada kecantikan wajah, tetapi juga kecantikan warna kulit, tubuh, rambut dan yang lainnya, menjadikan kaum perempuan target audience yang utama dalam dunia periklanan. Namun kini banyak pengiklan yang menggunakan model iklan perempuan khas Indonesia sebagai model iklannya, sehingga objek pembahasan adalah kecantikan khas perempuan Indonesia yang ditampilkan atau digunakan di dalam iklan media cetak berdasarkan latar belakang sosial budaya yang berkembang di Indonesia. Trend kecantikan perempuan umumnya banyak dipengaruhi oleh latar belakang sosial budaya suatu masyarakat. Metode penelitian yang digunakan adalah metode deskriptif dan analisis semiotika serta kajian perempuan untuk memberikan gambaran mengenai tampilan visual perempuan yang terdapat di dalam iklan media televisi. Dapat disimpulkan bahwa penggunaan tampilan perempuan dengan ciri khas Indonesia, warna kulit cokelat, merepresentasikan keberpihakan pengiklan pada segmen sasaran, sekaligus mempersuasi agar melakukan pembelian produk.
\end{abstract}

Kata kunci: Kecantikan, Perempuan, Iklan

Abstract: The beauty of women has always been the talked and
become trend in society. Beauty women are very diverse not limited
to facial beauty, but also the beauty of the color of skin, body, hair
and others, making women the main target audience in the
advertising world. But now a lot of advertisers who use advertising
models typical Indonesian women as a model of its ads, so the object

Penulis adalah mahasiswa program doctoral di Fakultas Seni Rupa Dan Desain Institut Teknologi Bandung, email: ira@tcis.telkomuniversity.ac.id 
of discussion is the unique beauty of Indonesian women displayed or used in print media advertising based on the socio-cultural background that is growing in Indonesia. Beauty trend women are generally more influenced by the socio-cultural background of a society. The method used is descriptive method and semiotic analysis and assessment of women to give an idea of the visual appearance of women contained in the television media advertising. It can be concluded that the use of women to see Indonesian characteristics, color brown, alignments representing advertisers in the target segment, while persuading in order to purchase products.

Key Words: Beauty, Women, Advertisement.

\section{PENDAHULUAN}

Kecantikan perempuan Indonesia sudah terkenal ke mancanegara, kecantikan khas khatulistuwa dengan warna kulit sawo matang, membuat kecantikan khas perempuan Indonesia ini semakin terkenal, namun tidak begitu fenomena yang terjadi di dalam negeri Indonesia sendiri, kaum perempuan di Indonesia cenderung tidak menyadari kecantikan alami mereka, bahkan kemudian meniru kecantikan perempuan dari luar negeri (Amerika, Korea, dan sebagainya). Bahkan tidak jarang perempuan Indonesia membeli produk kecantikan dari luar yang sangat mahal hanya untuk merubah penampilan mereka layaknya perempuan luar negeri. Tidak hanya konsumerisme pada produk kecantikan tetapi juga perawatan mahal yang dilakukan ke klinik kecantikan atau bahkan operasi plastik dilakukan demi mendapatkan kecantikan yang sempurna menurut mereka.

Perempuan Indonesia memiliki kecantikan alami yang khas, yakni adalah warna kulit sawo matang, karena untuk mendapatkan kulit sawo matang para turis dari mancanegara harus berjemur secara rutin agar mendapatkan warna kulit seperti yang dimiliki oleh perempuan Indonesia. Kecantikan lain yang 
dimiliki oleh kaum perempuan Indonesia adalah rambut hitam yang tebal. Kecantikan khas perempuan Indonesia tersebut tampaknya kini menarik perhatian para pengiklan, hal ini juga didukung oleh trend kecantikan saat ini yang sedang berpihak kepada ras timur. Sehingga penulis memandang bahwa terdapat pergeseran visualisasi model iklan perempuan khususnya di media televisi dari yang berwajah indo bergeser kepada perempuan yang memiliki kecantikan khas perempuan Indonesia.

Berdasarkan uraian diatas maka dirumuskan permasalahan sebagai berikut: Bagaimanakah visualisasi model perempuan dalam iklan kosmetik, dan bagaimanakah latar belakang budaya serta sosial mempengaruhinya? Adapun tujuan yang akan dicapai dalam penelitian ini adalah untuk mengetahui visualisasi model perempuan dalam iklan kosmetik dan latar belakang budaya serta sosial dalam mempengaruhi visualisasi iklan kosmetik.

\section{KAJIAN TEORI}

\section{Teori Perempuan}

Perempuan bukanlah suatu fakta yang ajeg, melainkan lebih merupakan keadaan yang selalu berada dalam proses menjadi, dan itu berarti kemungkinankemungkinan yang dimiliki perempuan harus didefinisi, bahwa tubuh bukanlah suatu benda, tubuh adalah situasi; tubuh adalah cengkeraman kita terhadap dunia dan sketsa rencana hidup kita. Dengan perkataan lain, meski tubuh tidak dapat mendefinisikan diri, tubuh menjadi satu elemen penting untuk menjadi diri tertentu. Tubuh adalah situasi yang berbeda tanpa kehilangan kesempatan untuk menikmatinya atau mengatasinya jika situasi itu dianggap bermasalah (Priyatna, 2014;112). 
Berdasarkan teori di atas maka dapat dibuat kerangka teori bahwa perempuan didefinisi, tubuh adalah suatu benda, tubuh adalah situasi. Situasi yang berbeda tanpa kehilangan kesempatan untuk menikmatinya atau mengatasinya jika situasi itu dianggap bermasalah.

Sehingga asumsi yang timbul dari pernyataan di atas adalah bahwa tubuh perempuan adalah bentuk definisi dari beragam kepentingan, contohnya model iklan perempuan dalam iklan pada dasarnya model tersebut tidak mendefinisikan dirinya sendiri, melainkan mendefinisikan situasi, mendefinisikan kepentingan pengiklan, produsen serta pihak-pihak lain yang terdapat di belakang terbentuknya sebuah iklan.

Perempuan tidak dapat berdiri sendiri, walaupun ia sebagai brand ambassador sebuah produk, perempuan tetap semu ia tetap membawa pesan atau makna lain di dalam tubuhnya. Tujuan dari periklanan juga dimasukkan ke dalam tubuh perempuan tersebut, gesture, mimik semuanya adalah milik si pengiklan bukan milik si perempuan.

\section{Teori Semiotika}

Dalam semiologi, makna denotasi dan konotasi memegang peranan yang sangat penting jika dibandingkan dengan peranannya dalam ilmu linguistik. Makna denotasi bersifat langsung, dan dapat disebut sebagai gambaran dari satu pertanda. Sedangkan makna konotatifnya akan sedikit berbeda dan akan dihubungkan dengan kebudayaan yang tersirat di dalam pembungkusnyatentang makna yang terkandung di dalamnya. Akhirnya, makna konotatif dari beberapa tanda akan menjadi semacam mitos atau petunjuk mitos (yang menekankan makna-makna tersebut) sehingga dalam banyak hal (makna) konotasi menjadi perwujudan mitos yang sangat berpengaruh (Berger, 2010;65). 


\section{METODE PENELITIAN}

Metode penelitian yang digunakan adalah metode deskriptif, yang bertujuan untuk melukiskan secara sistematis fakta atau bidang tertentu secara faktual dan cermat, metode ini juga menggunakan metode kualitatif. Metode kualitatif digunakan untuk memberikan deskripsi visualisasi model perempuan yang digunakan dalam iklan kosmetik di media televisi. Dengan menggunakan pendekatan sosial budaya, penulis akan mengaitkan visualisasi model iklan perempuan dalam iklan kosmetik dengan faktor-faktor sosial budaya yang berkembang di masyarakat. Faktor-faktor yang mempengaruhi perubahan sosial budaya perempuan Indonesia juga akan diteliti terutama yang bersangkutan dengan perkembangan teknologi, serta pengaruh budaya barat terhadap budaya perempuan Indonesia.

\section{HASIL DAN DISKUSI}

Indonesia yang kaya adat istiadat dan budaya mempengaruhi pandangan perempuan terhadap kecantikan khas alami Indonesia. Kecantikan khas alami perempuan Indonesia, khususnya suku Jawa mengandung tidak hanya sekedar persoalan fisik saja, namun juga mengandung unsur-unsur kebudayaan Jawa, seperti sikap lemah lembut yang menjadi ciri khas perempuan Jawa, hal ini mulai banyak disadari oleh beberapa kalangan yang bergerak dalam berbagai media massa, contohnya adalah iklan dalam media televisi.

Hal tersebut di atas terkait dengan teori yang disampaikan oleh Naomi Wolf, bahwa dalam konteks feminitas dan seksualitas wanita dalam iklan, tubuh wanita dikonstruksi untuk menyesuaikan dengan selera pasar, yang dalam hal ini pasar adalah kuasa yang menentukan apakah bentuk seksualitas atau feminitas (termasuk kecantikan, bentuk tubuh, jenis rambut dan sebagainya) diterima atau tidak. Perempuan akan bebas dari mitos kecantikan ketika kita dapat memilih 
untuk menggunakan wajah, tubuh dan pakaian kita sebagai salah satu bentuk yang sederhana dari ekspresi diri dari banyak lingkup ekspresi diri lainnya. Kita bisa berdandan untuk kesenangan diri kita, tetapi kita harus tetap memperjuangkan hak-hak kita." (Naomi Wolf, 2005; 550)

Konsep kecantikan di setiap daerah berbeda-beda, begitu pula rahasia kecantikan yang mereka miliki menjadi berbeda. Ini semua berdasarkan oleh suku dan ras tersebut. Di Afrika misalnya, rahasia kecantikan perempuan dilihat dari bibirnya. Bibir disebut sebagai simbol dari kecantikan perempuan di Afrika. Para wanita Afrika merias dan menonjolkan bibirnya sedemikian rupa agar nampak cantik dan menarik. Mereka menghias bibirnya dengan memasang piringan sehingga bibir mereka menjadi melebar. Semakin tinggi status sosial mereka, bibirnya semakin lebar. Sedangkan di Jepang, wanita Jepang yang cantik dilihat dari ukuran tubuhnya yang mungil, kulitnya yang mulus dan leher yang jenjang. Jika kita perhatikan memang wanita Jepang memiliki tubuh yang langsing. Hal ini dikarenakan pola hidup mereka yang sehat seperti olahraga teratur dan mengkonsumsi makanan rendah lemak namun tinggi protein dan anti-oksidan.

Di Indonesia, perempuan Jawa terkenal dengan kecantikannya karena sering menggunakan rempah-rempah alami sebagai bagian dari perawatan kecantikan pada setiap aspek tubuhnya. Mulai dari ujung rambut hingga ujung kaki ada resep tradisional untuk merawatnya. Penggunaan lulur dari beras, masker menggunakan buah. Selain rahasia kecantikan dari luar, perempuan Jawa juga menjaga kecantikannya dari dalam tubuh yakni dengan menggunakan jamu. Jamu merupakan resep turun temurun, hal ini membuktikan jamu mampu menjaga daya tahan tubuh dan juga menghaluskan kulit perempuan Indonesia. Selain kecantikan secara fisik, maka kecantikan alami khas perempuan khas 
Indonesia tercermin lewat sikap serta perilaku nya yang khas, yakni lemah lembut serta ramah.

Visualisasi perempuan Jawa sebenarnya telah banyak digunakan dalam beragam media massa, dari sejak tahun 1950-an sosok perempuan Jawa banyak digunakan dalam media massa seperti iklan, film serta tayangan televisi, namun seiring dengan perkembangan teknologi komunikasi dan informasi, maka semakin banyak kemudahan bagi kaum perempuan dalam mengakses kebutuhan informasi. Hal ini menyebabkan beragam pengaruh dari dunia barat masuk,dan kemudian banyak ditiru serta dicontoh oleh kaum perempuan di Indonesia, sehingga terjadi pemaknaan yang berlebihan terhadap kebudayaan barat oleh kaum perempuan di Indonesia, seperti salah satu contohnya adalah meniru kulit putih yang dimiliki oleh perempuan barat, bahkan pada tahun 1990-an, trend kecantikan tahun 1990 benar-benar mengadopsi kecantikan ala perempuan barat, yakni memiliki kulit yang putih dan tidak sekedar halus serta lembut.

Trend kecantikan kaum perempuan terus berkembang, sehingga kini sudah mulai ada kesadaran dari perempuan Indonesia yang memandang sisi lain dari kecantikan perempuan Indonesia yakni banyak perempuan Indonesia yang cerdas, tangkas dan memiliki prestasi di dunia internasional. Ini terbukti beberapa perempuan Indonesia tidak hanya menonjolkan penampilan fisiknya saja namun juga kepintaran dan kecerdasan, menjadikan perempuan Indonesia layak diberi apresiasi. Ini merupakan salah satu sifat inner beauty perempuan Indonesia. Sifat ramah tamah adalah salah satunya, sisi ramah tamah dan peduli terhadap lingkungan ini terbukti bahwa saat ini banyak perempuan Indonesia yang berperan serta dalam membangun bangsa. Berdasarkan uraian di atas maka disimpulkan bahwa dengan kesadaran tersebut maka banyak penggunaan 
visualisasi perempuan dengan kecantikan khas Indonesia yang dijadikan sebagai model iklan.

Sehingga dengan menyadari akan kecantikan khas alaminya, maka perempuan Indonesia akan terbebas dari mitos kecantikan yang diberikan oleh media massa, sehingga pada akhirnya tidak hanya persoalan penampilan fisik saja, tetapi juga merupakan bentuk ekspresi bebas kaum perempuan dalam menyuarakan hak-hak nya. Bahkan kini pihak media sudah berpihak serta lebih menonjolkan kecantikan alami khas perempuan Indonesia baik dalam tayangan televisi maupun dalam iklan.

Berikut penulis akan menganalisis makna yang terkandung di dalam iklan di bawah ini:

\section{Iklan Sariayu Versi Nias}

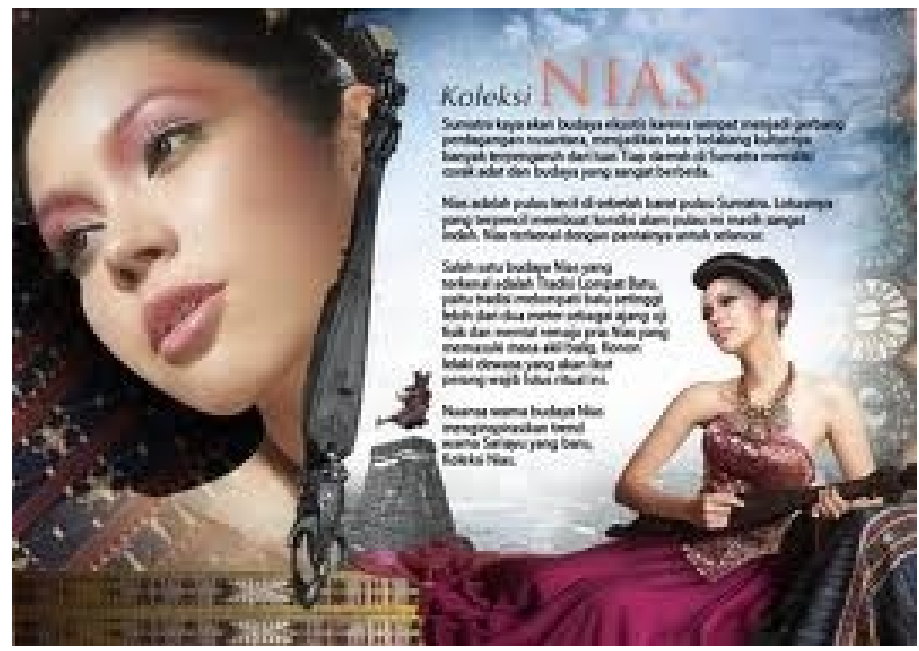

Gambar 1. Iklan Sariayu Versi Nias Sumber: Majalah Femina

Makna denotasi dalam iklan di atas adalah seorang perempuan Indonesia menggunakan baju adat suku Nias dengan memegang alat musik khas daerah Nias, yaitu rebana khas Nias. Maka konotasi yang terdapat dalam iklan tersebut 
adalah bahwa kecantikan serta penampilan perempuan tersebut merepresentasikan kecantikan khas Nias, penggunaan alat musik tradisional seolah menegaskan bahwa kecantikan perempuan tersebut terkait dengan tradisi kebudayaan Nias. Warna ungu yang digunakan oleh perempuan tersebut memberikan kesan megah dan kebijaksanaan.

Berdasarkan makna konotasi tersebut maka dapat disimpulkan bahwa iklan Sariayu versi Nias ini memberikan keyakinan-keyakinan kepada kaum perempuan untuk memiliki sikap bijaksana serta memiliki rasa kebanggaan terhadap budaya dan tradisi daerah Nias. Ideologi inilah yang ingin pengiklan sampaikan kepada target audience, yakni ideologi bijaksana, modern namun tetap memperhatikan kearifan lokal yang terdapat dari kebudayaan Nias.

Namun, sosok perempuan dalam iklan tersebut yang lebih sesuai dengan karakter perempuan indo dibandingkan dengan karakter perempuan Indonesia. Rupanya terdapat kekhawatiran dari pihak pengiklan untuk menggunakan perempuan asli Indonesia yang berkulit sawo matang, dan tidak memiliki hidung yang terlalu mancung. Pengiklan menggunakan sosok perempuan indo untuk tetap menarik perhatian target audience. Sehingga penulis dapat menganalisis bahwa pengiklan dari dalam negeri tetap mengangkat tema dan pesan sesuai dengan budaya Indonesia, namun hal ini nampak kontradiktif dengan penggunaan model iklan indo.

Seolah budaya barat dan budaya timur dipertentangkan dalam iklan ini, hal ini mungkin terpengaruh dari masih adanya rasa ketidakpercaya diri kaum perempuan Indonesia yang masih mengikuti trend kecantikan ala barat. Rasa tidak percaya diri ini sebenarnya merupakan representasi kebanyakan dari kaum perempuan, bangsa Indonesia dalam beberapa aspek belum memiliki rasa percaya diri yang baik, contohnya dalam bidang teknologi. Ditemukan juga hasil bahwa dalam iklan Sariayu Nias tersebut di atas terkandung pertentangan budaya antara budaya barat dan budaya timur, seolah pengiklan ingin 
memaksakan budaya Indonesia juga modern, global dan universal dengan menggunakan model perempuan berwajah indo.

\section{KESIMPULAN}

Kecantikan alami perempuan Indonesia yang telah mendunia ini hampir tidak dikenali serta diakui di negeri sendiri, karena banyak perempuan Indonesia sibuk mengoreksi kekurangan fisik mereka sehingga lupa dengan 'harta berharga'nya sendiri.

Perempuan Indonesia masih tetap mengikuti trend kecantikan dari luar negeri, sehingga hal tersebut digunakan oleh para pengiklan dengan tetap menggunakan model perempuan berwajah indo untuk mengiklankan produk kosmetik dari dalam negeri. Sebaiknya perempuan Indonesia bangga dengan kecantikan khas yang dimilikinya, sehingga penggunaan perempuan Indonesia dalam iklan akan banyak didominasi oleh penggunaan model iklan dengan kecantikan khas perempuan Indnonesia.

\section{DAFTAR PUSTAKA}

Berger, A.A., 2010. Pengantar Semiotika. Yogyakarta: Tiara Wacana.

Chaney, D., 1996. Lifestyles. Yogyakarta: Jalasutra.

Prabasmoro, A., 2006, Kajian Budaya Feminis. Yogyakarta: Jalasutra.

Priyatna, A., 2014. Perempuan Dalam Tiga Novel Karya NH. Dini. Bandung: Matahari.

Rakhmat, J., 2001. Metode Penelitian Komunikasi. Bandung: PT. Remaja Rosda Karya.

Rakhmat, J., 1986. Psikologi Komunikasi. Bandung: PT. Remaja Rosda Karya.

Sutisna, 2002. Perilaku Konsumen \& Komunikasi Pemasaran. Bandung: PT. Remaja Rosda Karya. 
Sobur, A., 2003. Semiotika Komunikasi. Bandung: PT. Remaja Rosda Karya.

Sutherland, M., 2005. Advertising and the mind of the consumer. Jakarta: PT. Gramedia Pustaka Utama.

Widyatama, R., 2005. Pengantar Periklanan. Jakarta: Buana Pustaka Indonesia.

Wolf, N., 2005. Mitos Kecantikan: Kala Kecantikan Menindas Perempuan. Jakarta: PT. Gramedia Pustaka Utama. 